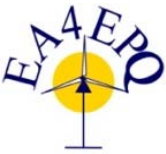

International Conference on Renewable Energies and Power Quality (ICREPQ'17) Malaga (Spain), $4^{\text {th }}$ to $6^{\text {th }}$ April, 2017

Renewable Energy and Pourer Qualily. Fournal (RE\&PQJ)

ISSN 2172-038 X, No.15 April 2017

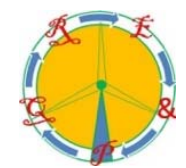

\title{
THE BRAZILIAN AUTOMOTIVE INDUSTRY AND SUSTAINABILITY
}

\author{
Nilcéia Cristina dos Santos ${ }^{1}$, Reinaldo Gomes da Silva ${ }^{2}$, Maria Helena Bernardo Myczkowski ${ }^{1}$ \\ ${ }^{1}$ Faculdade de Tecnologia de Piracicaba "Dep. Roque Trevisan" (FATEC PIRACICABA) \\ CEETPS, Centro Estadual de Educação Tecnológica Paula Souza \\ Av. Diácono Jair de Oliveira, S/N, Piracicaba/SP (Brazil) \\ Phone number: +55 19 99614-1327 or +55 19 3411-2454 \\ E-mail: nilceia_santoss@yahoo.com.br,ncsantoss@hotmail.com, mariahelenabernardo@hotmail.com
}

\author{
${ }^{2}$ Escola de Engenharia de Piracicaba (EEP) \\ FUMEP, Fundação Municipal de Ensino de Piracicaba \\ Av. Monsenhor Martinho Salgot, 560, Piracicaba/SP (Brazil) \\ Phone number: +55 19 99602-1218 \\ E-mail: reinaldorgda@gmail.com,reinaldo@eep.br
}

\begin{abstract}
The automotive industry in Brazil is highly diversified in the production of vehicles (cars, trucks, buses, and light commercial vehicles). Since the 1970s, Brazil has experienced changes in the vehicle energy matrix, with the appearance of ethanol fuel as an alternative to oil. The use of ethanol produced from sugar cane, followed by biodiesel and modest advances in the use of electrical batteries in cars, has put the country on the path to energy sustainability. Currently, the technological innovations of the automotive industry have been concerned with developing electric and hybrid vehicles, as is the case with hybrid vehicles that are powered by hydrogen fuel cells or batteries (lead or lithium). The Brazilian automotive industry has thus contributed to the search for sustainability. It has a long way to go in that direction, however, because the use of diesel engines in trucks and buses accounts for the largest portion of air pollution in Brazilian cities. Brazilian legislation plays an important role in the quest for sustainability. More stringent legislation for reducing the emission of gaseous pollutants in all types of vehicles, and improvements in the enforcement of vehicle regulation, represent a huge leap forward in this regard. The efforts of the automotive industry in Brazil, along with technological developments, can contribute to the reduction of emissions of polluting gases, and the introduction of public transportation via trains, subways, and monorails that use electricity can do likewise. All of these are important contributions to the reduction of air pollution in Brazilian cities, and to the sustainability that we all so badly need.
\end{abstract}

KEYWORDS: electric vehicles, automotive industry, sustainability.

\section{INTRODUCTION}

The automobile industry is highly diversified, and in Brazil there are conditions that allow it to develop in a sustainable way, combining economic growth, social inclusion, and environmental conservation.

The issue of sustainability concerns all countries and should be treated differently in each industrial sector, considering the specificities of each one. However, the are some elements in common, such as the search for efficiency in the use of resources and the need to increase industrial competitiveness.

Sustainable practices in each industrial sector must be implemented in the midst of supply chains, and there should also be incentives for companies to undertake initiatives of integrated management and coordinated action for more sustainable production.

According to the Brazilian National Confederation of Industries (CNI), the theme of sustainability is more than a matter of principle, and has become a necessity for global world society, for socio-economic and environmental stability, and for preserving the future of humanity (CNI, 2012).

The automobile industry has the characteristics of a structured industry, introducing technologies and generating new economies in a wide field of activities. From the raw materials and inputs, to the supplier industries and assembly lines, to the subsequent marketing network and the end consumer, the automotive industry and its products have profound impacts on sustainability that can be seen in the social, media, economic environment.

The auto industry seeks sustainable models of operation in its industrial activities and the performance and use of its products, as well in as its socio-economic effects on the communities in which it is located (CNI, 2012).

In Brazil, there are public policies that aim to increase the efficiency of both new and used vehicles, and to diversify the energy matrix by using alternatives to fossil fuels (ethanol and biodiesel). There has also been considerable technological innovation by the automotive industry, in order to develop vehicles powered by electricity and to develop hybrids that combine electricity 
(hydrogen fuel cells and lead or lithium batteries) with other fuel sources (RIBEIRO AND REAL, 2006; RIBEIRO AND ABREU, 2008; SILVA, 2011).

In quantitative terms, according to data from the National Association of Vehicle Manufacturers (ANFAVEA), in 2015 about 2.5 million assembled vehicles (cars, light commercial vehicles, trucks, and buses) were produced in Brazil, a decrease of $29.4 \%$ compared to the volume produced in 2014 (ANFAVEA, 2016). Even with this decline in production, a result of the current Brazilian political and economic situation, the automotive industry and the automotive market in Brazil are among the world's largest. Brazil is the world's fourth largest automotive market and world's eighth largest automotive producer (ANFAVEA, 2016).

In this context, the present study has the objective of analyzing the measures adopted by the Brazilian automotive industry with regard to sustainability. The methodology consisted in bibliographical research by means of books, articles, and academic theses covering the Brazilian auto market, electric vehicles, and environmental pollution.

The economic, technological, sociocultural, and environmental transformations that society has undergone seem to indicate a change in the role of vehicles, which are considered responsible for the emission of carbon dioxide $\left(\mathrm{CO}_{2}\right)$ and its environmental and economic impacts.

\section{LITERATURE REVIEW}

This literature review aims to expound some concepts and information that will facilitate on understanding of the Brazilian automotive market and the issue of sustainability in Brazil.

\subsection{The Brazilian Automotive Market}

The Brazilian automotive industry is among the world's largest producers of vehicles. Automobile manufacturers in the country are responsible for the production of various types of vehicles, and most of these companies produce more than one product category. There are 20 vehicle manufacturers (cars, light commercial vehicles, trucks, and buses) and 7 producers of agricultural machinery (tractors, harvesters, and other vehicles) (ANFAVEA, 2016).

With regard to the situation in Latin America, the production and marketing of automotive vehicles has grown exponentially in recent years. In 2015, as stated earlier, Brazil sold 2.5 million domestic vehicle units, representing more than $36.1 \%$ of the existing motor vehicles in Latin America (Argentina, Bolivia, Chile, Colombia, Ecuador, Paraguay, Peru, Uruguay, Venezuela, and Mexico) (ANFAVEA, 2016).

The automotive industrial complex and economic chain consists of the auto supply industry and vehicle and agricultural machinery manufacturers. It also develops automotive engineering and highly qualified staff, as well as marketing and service sectors covering the whole country. This chain of activity is shown in Figure 1.

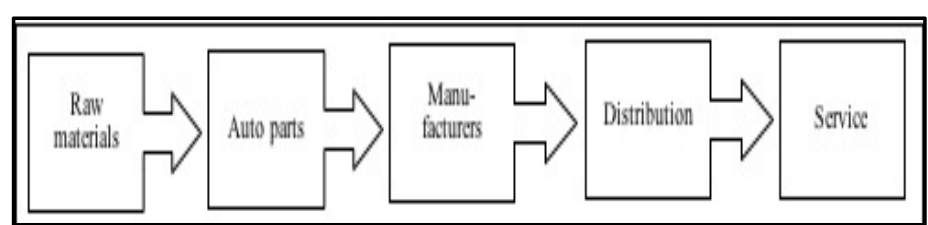

Figure 1 - Automotive Economic Chain

The raw materials phase is comprised of companies responsible for the production of steel, plastics, rubber, glass, textiles, and paints. The auto parts phase includes companies from sectors that manufacture engines, transmissions, brakes, tires, wheels, chassis, and axles. The manufacturers produce and assemble cars, light commercial vehicles, trucks, buses, tractors and harvesters. Dealerships distribute vehicles to the end consumer and are the fourth stage of the economic chain. Finally, the service stage includes post-sales services, fuel distributors, insurers, banks responsible for vehicle financing, auto parts stores, and auto repair shops.

The Brazilian automotive industry has plants around the country, manufacturing both vehicles end products (such as auto supply industry products). In the case of vehicle and agricultural machinery manufacturers, their are 31 companies with 65 plants, based in 51 municipalities in 11 Brazilian states. These plants are found in the Central-South, Midwest, and North-Northeast regions, that is, in all regions of country, and have a total capacity of 4.5 million units of vehicles and 109,000 units of agricultural machinery (ANFAVEA, 2016).

This decentralization of automotive investments creates new local and regional economies, adding jobs, income, consumption, and quality of life in a virtuous circle, in addition to acting as a factor in local, regional, and national sustainability.

\subsection{The Brazilian Vehicular Energy Matrix}

Around the world there is now ongoing intense research and development with regard to innovation and technologies for the sustainability chains of vehicular energy matrixes involving fuels and vehicles (CNI, 2012).

In the area of fuels, new alternatives to fossil fuels are renewable biofuels, synthetic fuels, and fuel cells. In the engine area, there are current developments aimed at greater energy efficiency for internal combustion engines, hybrid vehicles, and electric motors.

In the current Brazilian fleet, flex-fuel and gasoline-only vehicles predominate,. The introduction of electric and hybrid vehicles, especially purely electric vehicles, requires investment in infrastructure and technology, and is highly dependent on government incentives.

According to the CNI (2012), the global vehicular energy matrix tends to be multiple, with a predominance of one form or another according to the resources available in each region and the automotive consumption scale. In Brazil, in the short and medium term, technical and economic feasibility favors the combustion engine, with the use of oil products and of biofuels such as ethanol and biodiesel. There are individual cases of the use of 
hybrid or electric vehicles in certain niches, generally for company and institutional fleets.

With regard to ethanol fuel, Brazil is a world pioneer in the large-scale use of renewable biofuel for powering vehicles.

In 2015, the Brazilian fleet of domestic and imported automotive vehicles totaled 2,121,956 units, $6.31 \%$ of which driven only by gasoline, $92.31 \%$ flex-fuel vehicles, powered by gasoline and ethanol, $1.33 \%$ units driven by diesel and electric vehicles, account for only $0.04 \%$.

The technological, economic, and social effects of this activity are great, and include the development of new technologies, job creation, and improvement in family income, as well as increased consumption and quality of life in regions where renewable fuel is produced. The automotive industry itself also benefits from the production of flex fuel vehicles (CNI, 2012). Alongside these socioeconomic benefits are the environmental benefits of the production and consumption of ethanol, with the reduction of $\mathrm{CO}_{2}$ emissions in the atmosphere.

Brazil has also begun to develop the Biodiesel Program and started to add 5\% biodiesel (esterified vegetable oil, renewable biomass) to diesel fuel consumed by freight transport and passenger vehicles within the country. According to the CNI (2012), this program can transform the sustainable economic chain, with strong economic, social, and environmental consequences, particularly with regard to social inclusion through family agriculture in the production of raw materials for fuel. Furthermore, the program can have positive effects on environmental balance and the generation of new economies in the country's interior regions.

Automotive products have long life cycles, and this represents significant impacts on society in terms of environment, urban mobility, traffic safety, and sustainability.

Continuous investment in vehicle innovation has become crucial with regard to engines and alternative fuel technologies, as well as with regard to the actual design and overall performance of automotive products.

In the case of emissions, light and heavy Brazilian vehicles must comply with the appropriate legislation, resulting in the reduction of carbon monoxide (CO), hydrocarbons ( $\mathrm{HC})$, nitrogen oxide (NOx), total aldehydes $(\mathrm{CHO})$, and particulate matter (PM).

On May 6, 1986, the Brazilian National Environmental Council (CONAMA) created, through Resolution No. 18, the Air Pollution Control Program for Motor Vehicles (PROCONVE), coordinated by the Brazilian Institute of Environment and Renewable Natural Resources (IBAMA). This program defined emission limits for light vehicles, in order to contribute to the air quality standards established by PRONAR (National Program for Air Quality) (CONAMA, 2012).

PROCONVE was divided into stages, so that companies would have time to adjust to the new emissions limits. Phase L-1 (1988), for light vehicles, consisted of eliminating the highest polluting vehicles and enhancing production; In Phase L-2 (1992), vehicles had to adopt new technologies such as electronic fuel injection and catalytic converters. Since ethanol is used along with gasoline, an intensive application of technology was needed to implement the use of catalytic converters and electronic injection; Phase L-3 (1997) was responsible for adding oxygen sensors to engines; Phases L-4 (2003), L-5 (2009), and L-6 (2012) are characterized by lower emission levels, not requiring manufacturers to install equipment or items in engines, as had been done in earlier stages (SCHOLL, 2009).

As a result of PROCONVE, a Brazilian car today emits 28 times less emissions than a vehicle produced in 1980 (CNI, 2012).

Despite the reduction in levels of pollutants, it is necessary to stimulate alternative sources of energy to reduce the use of fossil fuels, using electric vehicles (cars, trucks, buses, light commercials vehicles), increasing the biodiesel and ethanol participation in the composition of fossil fuels and promoting tax incentives for the production of electric vehicles in Brazil.

\subsection{Industrial Matrix}

Environmental issues should be one of the pillars of the sustainability of the industrial matrix of the automotive sector, together with the ecology of its products. Systems, processes, and management for improved environmental quality, with clean production processes, economizing of resources, waste reduction, and treatment and reduction of waste, as well as competence and productivity gains in companies, are the basis for sustainability in businesses.

With regard to the environmental issues relevant to the automobile industry, key indicators show a reduction in input consumption per vehicle produced. Also relevant is the reduction of greenhouse gases. This scenario is complete with waste and recycled waste indicators (CNI, 2012).

The main forms of waste in the automotive industry are shown in Table 1.

\begin{tabular}{|l|l|}
\hline \multicolumn{1}{|c|}{ MATERIAL } & \multicolumn{1}{c|}{ GENERAL PROCESS } \\
\hline Scrap metal & Separation, transport, recycling \\
\hline Oils and paints & Storage, recycling, co-processing \\
\hline Hazardous waste & Storage,co-processing, incineration \\
\hline Inert waste & Recycling, industrial landfills \\
\hline
\end{tabular}

Table 1 - Main forms of waste in the automotive industry Source: CNI (2012, p. 34)

Waste policies and the principles of environmental and social sustainability adopted by the assembly plant industry permeate all supply chains prior and subsequent to assembly lines, aligning suppliers of raw materials and intermediaries, as well as logistics and dealers which must operate based on principles of green economy, with clear targets and goals.

Vehicle production needs move toward innovations and technologies that enhance the environment, urban mobility, and traffic safety, and its projects should emphasize compact cars, energy efficient engines, lower consumption, lower emissions, and the use of alternative fuels (CNI, 2012).

Electronics, computing, and connectivity, in many different forms, are and will be a growing presence in vehicles, activating them and powering them, defining 
routes, and providing greater drivability, along with time and resource savings, traffic safety, and environmental quality. New materials and nanotechnology make vehicles lighter and also more recyclable at the end of their life cycle.

\subsection{Sustainability and automotive sector}

Discussions of sustainability, which cite the pursuit of resource use in the short term without compromising long-term needs and the conditions for future generations (WCED, 1987), have also been relevant to the discussion of the role of businesses. This is because businesses are in possession of great economic, social, and political power, and can influence to a large extent the contexts in which they operate (HART, 2007).

The role of the automobile industry in this context is and must be relevant. It is industry's task to develop and produce technologically suitable vehicles that promote the reduction of fuel consumption, emit lower levels of emissions and noise, use alternative fuels, and that are able to operate within the required vehicle safety standards (CNI, 2012).

The transport sector is responsible for $25 \%$ of primary energy consumption worldwide (FAPESP, 2007) and accounts for more than a quarter $(28 \%)$ of $\mathrm{CO}_{2}$ emissions in Europe (COMISSÃO EUROPEIA, 2001).

The issue of greenhouse gas emissions from cars is considered to be one of the current problems which has led the automotive industry to seek the improvement of internal combustion engine efficiency (motivated by the reduction of $\mathrm{CO}_{2}$ emissions), and to develop vehicles powered by alternative energy sources such as alternative fuels (natural gas, biodiesel, ethanol), electricity (battery, solar, hybrid, fuel cells), hybrid energy sources, and hydrogen cells (GOLDSTEIN AND AZEVEDO, 2006).

Involving the auto industry in issues of sustainability such as green buildings, eco-design, green supply chains, green manufacturing, reverse logistics, and innovation, is necessary and urgent (NUNES AND BENNETT, 2010).

There are studies that point to factors that decisively influence the issue of sustainability in the automotive sector, among the main ones being innovation (TRIEBSWETTER AND WACKENBAUER, 2008), newly discovered technologies (HOED AND VERGRAGT, 2004), the adoption of socially responsible practices (MARTINUZZI et al., 2011), and the recycling and reuse of materials (CHEN, 2006).

\section{FINAL CONSIDERATIONS}

An understanding of the Brazilian automotive market and its main challenges with regard to sustainability is critical to the development of public policies relevant to the most dynamic sector of the Brazilian economy. The domestic auto industry is the driver of a large industrial complex formed by industry, automotive suppliers, raw materials and products, recycling, and final disposal. It involves industry and the service sector, employing thousands of workers and generating millions in taxes at all levels of government.
The vehicle energy matrix in Brazil stands out in its use of ethanol and, to a lesser extent, biodiesel. The Brazilian car fleet includes mainly flex-fuel vehicles, as well as gasoline-only cars and vehicles that run exclusively on biofuels. The introduction of electric and hybrid vehicles is still negligible compared to the total number of vehicles in circulation. The widespread use of such vehicles requires investments in infrastructure and technology, and is dependent on government incentives. Although new vehicles meet the requirements of the legislation in terms of pollution, the Brazilian fleet is old and highly polluting, with the emission of gases that cause the greenhouse effect.

The Brazilian automotive industry matrix has sought to advance the use of technologies that allow for the substitution of oil, centering on engines in the case of ethanol cars. As for light commercial vehicles, and trucks and buses that use fossil fuels (diesel), the solution has been the use of biodiesel mixed with diesel, but on a small scale. The biggest problem in this is case a fleet of vehicles (light commercial vehicles, buses, and trucks) which is quite old and uses only diesel as fuel. This fleet needs to be replaced or, at least, the effects of these vehicles need to be mitigated with the introduction of catalytic converters and other mechanisms for the reduction of $\mathrm{CO}_{2}$ emissions.

In the discussion of energy sustainability and use of urban vehicles, the automotive industry is key to the search for solutions for transporting people and freight. The growth of cities and of population requires rethinking the use of all types of transport, and specifically the use of fossil fuel. The pursuit of sustainability requires the involvement of all stakeholders (government, consumers, and industry). The automotive industry in particular is responsible for producing vehicles that are necessary for modern life in cities across the globe, but at the same time the vehicles it produces are the main source of pollution of the cities in Brazil and around the world.

\section{REFERENCES}

[1] ANFAVEA. Brazilian Automotive Industry Yearbook 2016. 2016. Available at: $<$ http://www.anfavea.com.br/anuario.html $>$. Accessed on: $28 / 10 / 2016$.

[2] CHEN, M. Sustainable Recycling of Automotive Products in China: Technology and Regulation. Journal of the Minerals, Metals and Materials Society (JOM), 58(8), 23-26, 2006.

[3] CNI. ndústria automobilística e sustentabilida. 2012. Confederação Nacional daI ndústria. Associação Nacional dos Fabricantes de Veículos Automotores. B rasília : CNI, 2012.

[4] COMISSÃO EUROPEIA. Livro Branco: A Política Europeia de Transportes no Horizonte 2010 - a Hora das Opções, 2001. http://ec.europa. eu/transport/themes/strategies/doc/2001 white_paper/lb_texte_complet_pt.pdf Acesso em $09 / 11 / 2016$.

[5] CONAMA - Conselho Nacional do Meio Ambiente. Resoluções do CONAMA: publicadas entre setembro de 1984 e janeiro de 2012. Ministério do Meio Ambiente. Brasília: MMA, 2012. 
[6] GOLDSTEIN, M.; AZEVEDO, R.L.S. Combustíveis alternativos e inovações no setor automotivo: será o fim da "era do petróleo"? BNDES Setorial, Rio de Janeiro, n. 23, p. 235-266, mar. 2006.

[7] HART, S.L. Capitalism at the crossroads. Upper Saddle River: Wharton School Publishing, 2nd Ed., 2007.

[8] HOED, R. VAN DEN; VERGRAGT, P. J. Institutional change in the automotive industry. Greener Management International, (47), 45-62, 2004.

[9] MARTINUZZI, A.; KUDLAK, R.; FABER, C.; WIMAN, A. CSR Activities and Impacts of the Automotive Sector, RIMAS Working Papers, No.3, 2011, Disponível em http://www. sustainability.eu/pdf/csr/impact/IMPACT Sector_Profile_AUTOMOTIVE.pdf Acesso em 30/10/2016.

[10]NUNES, B.; BENNETT, D. Green operations initiatives in the automotive industry: An environmental reports analysis and benchmarking study, Benchmarking: An International Journal, Vol. 17 Iss: 3, pp.396 - 420, 2010.

[11] RIBEIRO, Suzana K.; ABREU, Adrianna. A. (2008). Brazilian Transport Initiatives with GHG Reductions as a co-benefit. Climate Policy. v.8, n.2, p. 220-240.

[12] RIBEIRO, Suzana K.; REAL, Márcia V.. Novos Combustíveis. Rio de Janeiro: E-papers, 2006.

[13] SCHOLL, Evandro. Emissão de poluentes por automóveis. 2009. UNIVILLE. 04/2009.

[14] SILVA, Elenice Rachid. Análise do crescimento da motorização no Brasil e seus impactos na mobilidade urbana. 2011. 142p. Dissertação (Mestrado do Programa de Planejamento Energético/COOPE) Universidade Federal do Rio de Janeiro (UFRJ), Rio de Janeiro. 2011.

[15] TRIEBSWETTER, U.; WACKERBAUER, J. Integrated environmental product innovation and impacts on company competitiveness: a case study of the automotive industry in the region of Munich. Environmental Policy and Governance. Volume 18, Issue 1, p. 30-44, January/February, 2008.

[16] WCED, (1987) Our Common Future, World Commission for the Environment and Development, Oxford, Oxford University Press. 